\title{
DRILLING, CONSTRUCTION, AND CALIPER-LOG DATA FOR WELL 3-3503-01, NORTH UPPER ANAHULU EXPLORATORY WELL, OAHU, HAWAII
}

U.S. GEOLOGICAL SURVEY

Open-File Report 96-427

Prepared in cooperation with the CITY AND COUNTY OF HONOLULU BOARD OF WATER SUPPLY
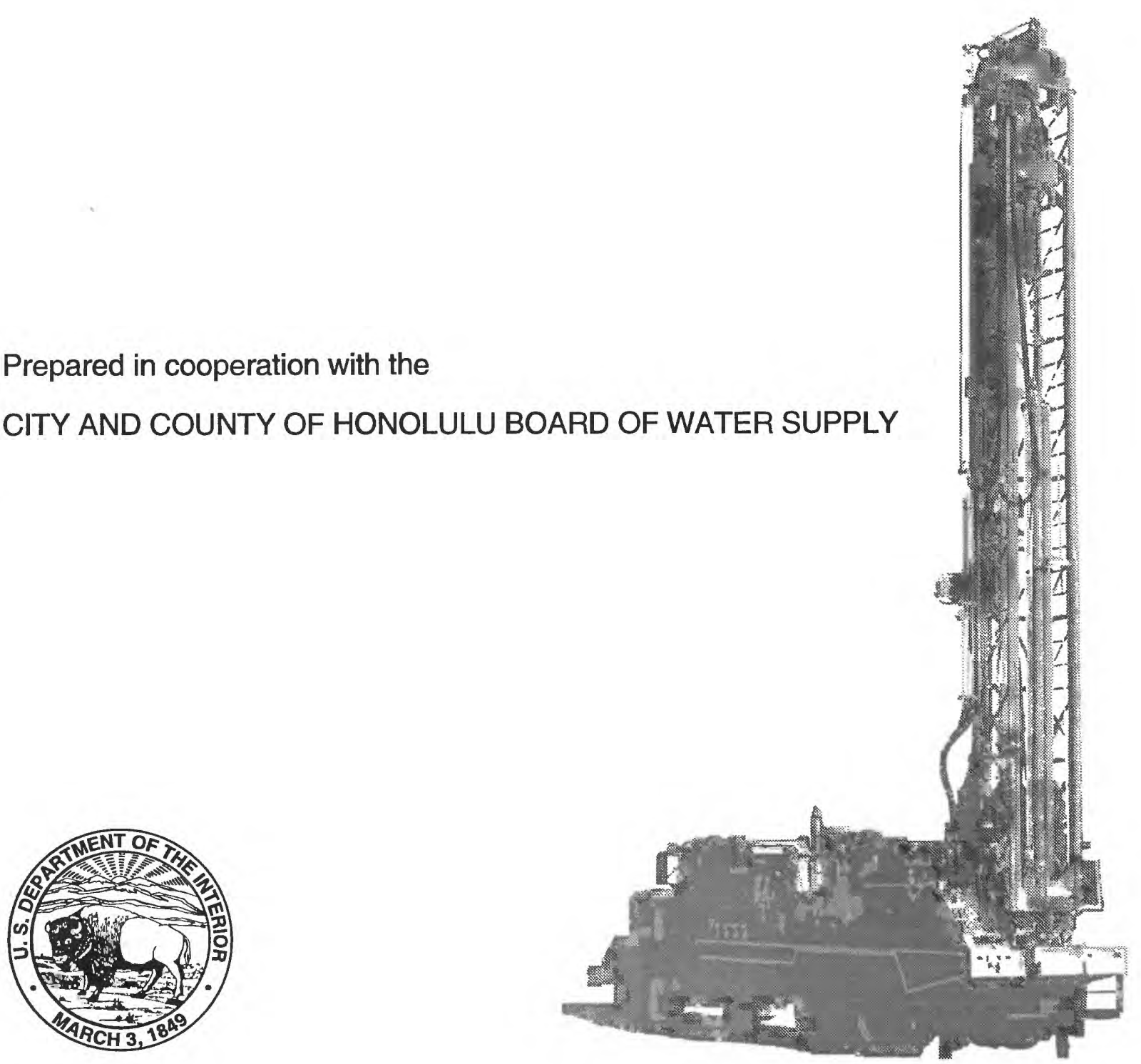


\title{
U.S. DEPARTMENT OF THE INTERIOR BRUCE BABBITT, Secretary
}

\author{
U.S. GEOLOGICAL SURVEY \\ Gordon P. Eaton, Director
}

Any use of trade, product, or firm names in this publication is for descriptive purposes only and does not imply endorsement by the U.S. Government

For sale by the

U.S. Geological Survey

Branch of Information Services

Box 25286

Denver, CO 80225-0286

For additional information write to:

District Chief

U.S. Geological Survey

677 Ala Moana Blvd., Suite 415

Honolulu, HI 96813 


\section{CONTENTS}

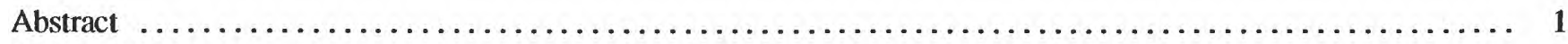

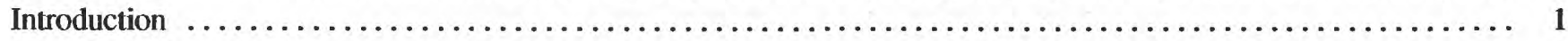

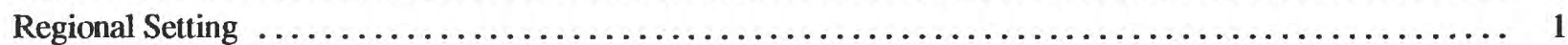

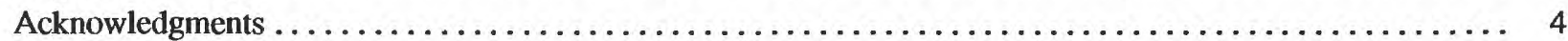

Drilling, Construction, and Caliper-Log Data. . . . . . . . . . . . . . . . . . . . . . . .

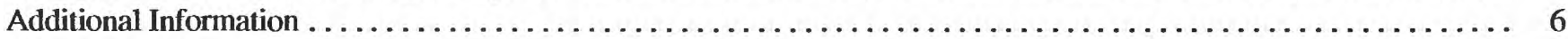

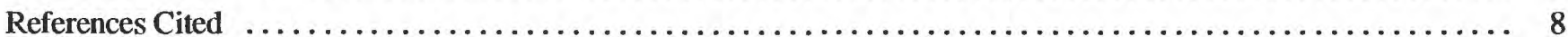

\section{FIGURES}

1-2. Maps showing:

1. Ground-water areas of north-central Oahu, and wells drilled during the study, Hawaii . . . . . . . . 2

2. Location of North Upper Anahulu exploratory well, Oahu, Hawaii . . . . . . . . . . . . . . . 3

3. Diagram showing construction details for the North Upper Anahulu exploratory well (State well number $3-3503-01$, Oahu, Hawaii . . . . . . . . . . . . . . . . . . . . . . .

4. Graph showing caliper log for North Upper Anahulu exploratory well (State well number

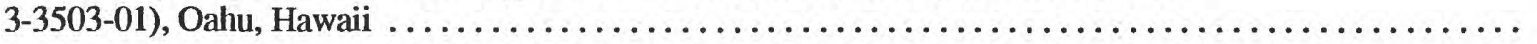

\section{TABLES}

1. Construction data for North Upper Anahulu exploratory well, Oahu, Hawaii . . . . . . . . . . . . . . . . 4

2. Geologic log for North Upper Anahulu exploratory well (State well number 3-3503-01), Oahu, Hawaii. . . . . . . . 6

3. Driller's log for North Upper Anahulu exploratory well (State well number 3-3503-01), Oahu, Hawaii . . . . . . . . 9

4. Construction data for wells drilled during the study, Oahu, Hawaii $\ldots \ldots \ldots \ldots \ldots$

\section{Conversion Factors}

\begin{tabular}{rcll}
\hline Multiply & By & To obtain \\
\hline foot (ft) & 0.3048 & meter \\
mile (mi) & 1.609 & kilometer \\
inch (in.) & 25.4 & millimeter \\
\hline
\end{tabular}

Elevations in this report are referenced relative to mean sea level. 


\section{Drilling, Construction, and Caliper-Log Data for Well 3-3503-01, North Upper Anahulu Exploratory Well, Oahu, Hawaii}

\author{
By Todd K. Presley and Delwyn S. Oki
}

and to provide a water-level observation well for monitoring.

\section{Regional Setting}

The study area is located in north-central Oahu between the crests of the Koolau Range and the Waianae Range (fig. 1). Previous studies (Rosenau and others, 1971; Dale, 1978; Hunt, in press) that describe the physical and geological aspects of the study area are summarized here. The mountain ranges are the eroded remnants of two shield volcanoes. The Mokuleia and Waialua ground-water areas are separated by low-permeability paleosols and saprolite of the Waianae Volcano that lie below the geologic contact between the Waianae and Koolau Volcanoes. The Waialua and Kawailoa ground-water areas are separated by alluvium and weathered basalt in and beneath Anahulu Gulch. Seaward flow of ground water in the Mokuleia and Waialua ground-water areas is impeded by a coastal confining unit that is composed of marine and terrestrial sediment known locally as "caprock." The caprock creates a confined artesian condition at low elevations near the shore. Further inland however, the aquifer is unconfined.

Water levels in the Waialua and Kawailoa groundwater areas are about $12 \mathrm{ft}$ and $4 \mathrm{ft}$, respectively, above mean sea level. Water levels in the Mokuleia groundwater area are about $20 \mathrm{ft}$. Withdrawal from the Waialua, Kawailoa and Mokuleia ground-water areas is primarily for sugarcane irrigation, although there are also several municipal wells and numerous small capacity private wells. Natural ground-water discharge occurs at springs and by subsurface flow through the caprock to the ocean (Rosenau and others, 1971). 


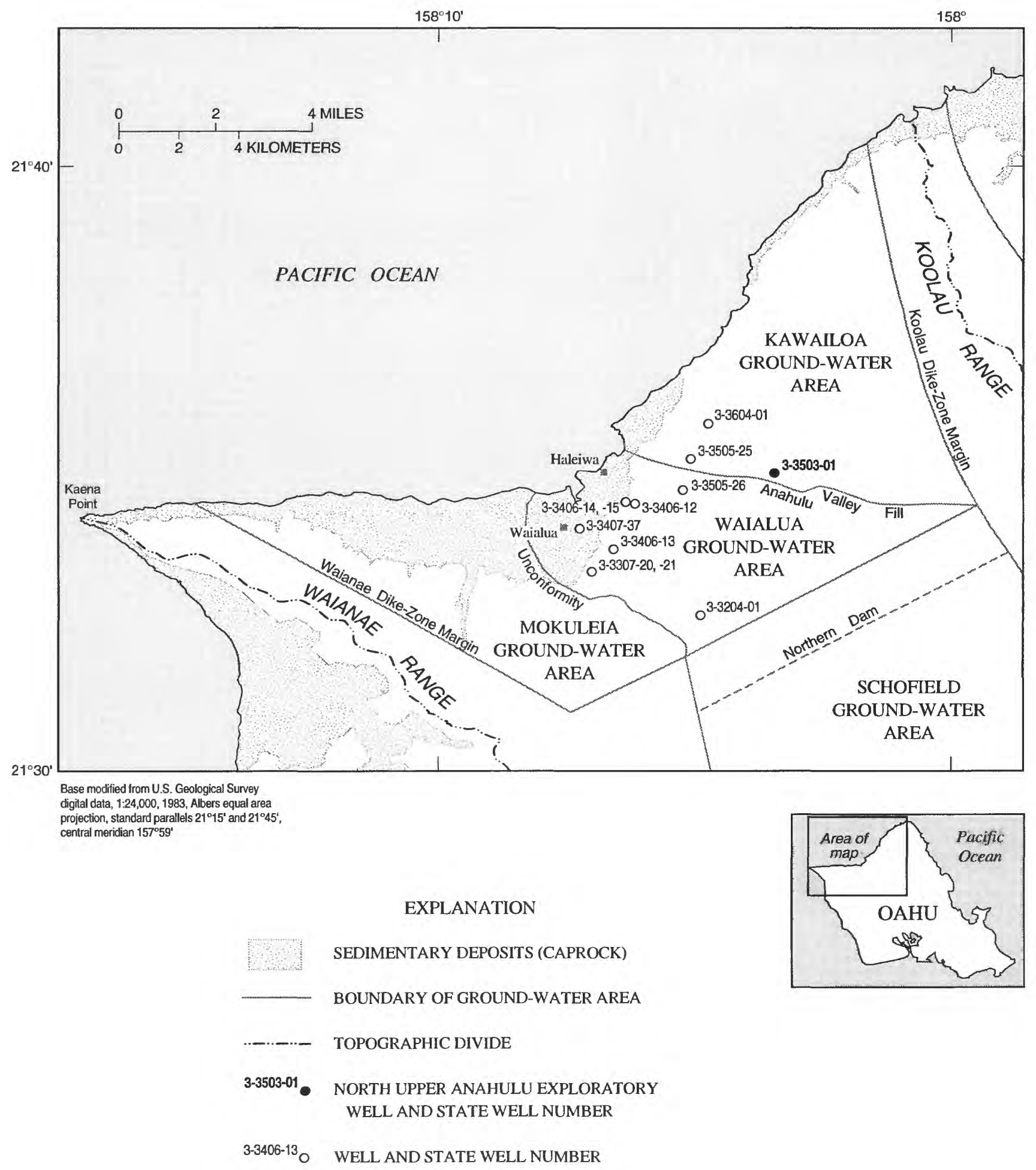

Figure 1. Ground-water areas of north-central Oahu (modified from Hunt, in press) and wells drilled during the study, Hawaii. 


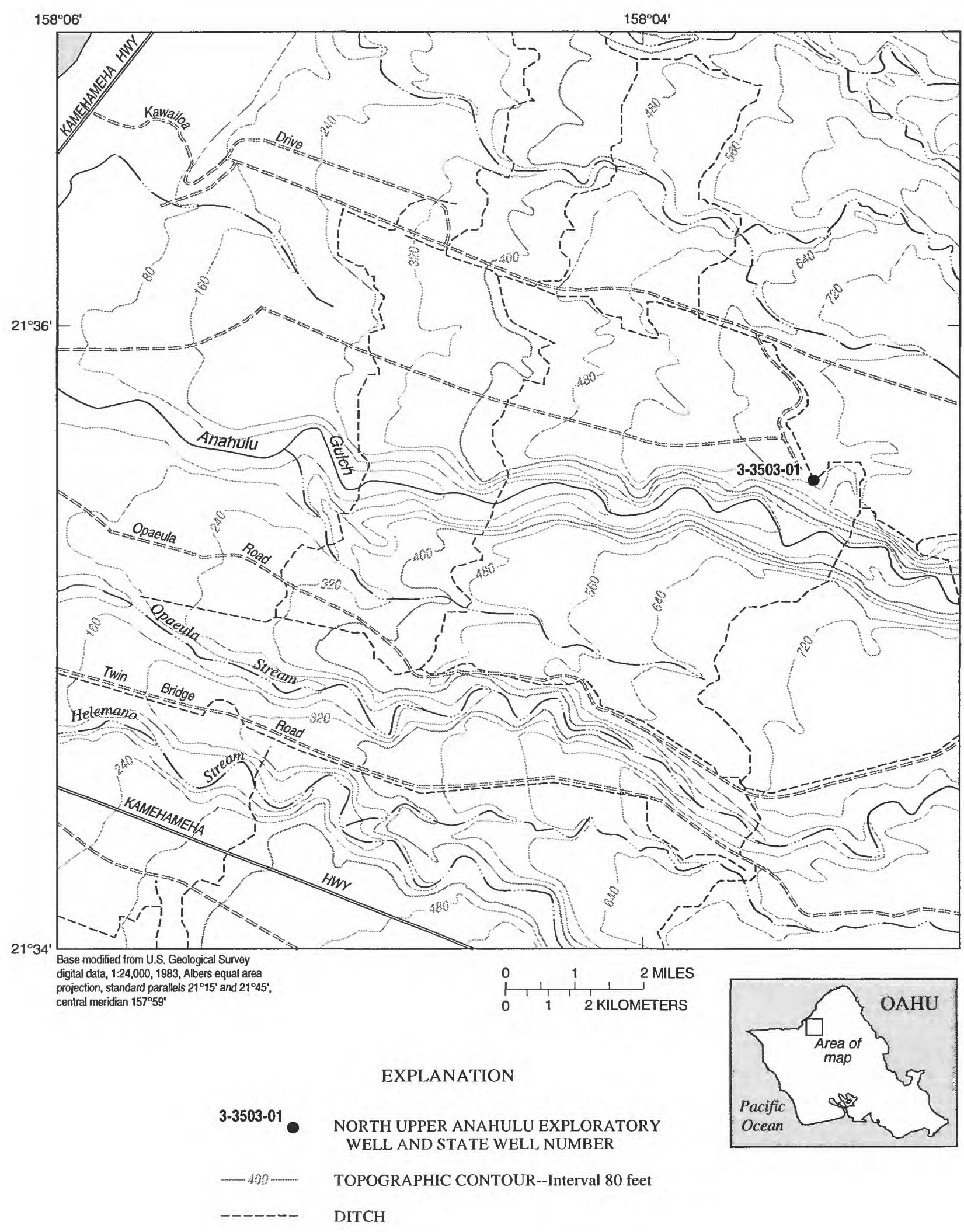

Figure 2. Location of North Upper Anahulu exploratory well, Oahu, Hawaii. 


\section{Acknowledgments}

The USGS gratefully acknowledges the Waialua Sugar Company for their assistance in identifying and preparing the drill site. The USGS also thanks the Bernice Pauahi Bishop Estate for permission to drill on their land.

\section{DRILLING, CONSTRUCTION, AND CALIPER-LOG DATA}

The North Upper Anahulu exploratory well (State well number 3-3503-01) is $3.1 \mathrm{mi}$ east of the town of Haleiwa on the north side of Anahulu Gulch (fig. 1). The site is located along a peripheral road of a sugarcane field (fig. 2). Well-construction data is provided in table 1 and construction details are shown in figure 3.

The North Upper Anahulu exploratory well was drilled using an air-rotary system with flush-jointed 4 1/2-in. diameter drill pipe. Drilling foam and polymer were injected into the air-circulation system to assist the removal of drill cuttings and to stabilize the hole. The elevation of the ground surface in the area of the drill site is about $670 \mathrm{ft}$ above mean sea level. A 12 1/2-in. diameter hole was drilled to an elevation of $592 \mathrm{ft}$ and cased with $80 \mathrm{ft}$ of $85 / 8$-in. outside-diameter steel cas- ing. The annular space was grouted with cement to provide a surface seal. An $63 / 4$-in. diameter tri-cone tungsten-carbide button bit was then used to drill to an elevation of -103 . After the total depth was reached, a Well Reconnaissance logging unit was used to record a caliper log. The well was cased with $41 / 2$-in. outsidediameter flush-jointed steel casing. Slotted, 4 1/2-in. outside-diameter steel casing was installed through the water column.

Samples of the materials expelled by the circulation system while drilling were collected every $5 \mathrm{ft}$. After a depth of $230 \mathrm{ft}$ was reached, the circulation was completely absorbed by the formation and no sample was recovered. The geologic log (geologic descriptions of the recovered samples from drilling) is presented in table 2, and the driller's $\log$ (driller's observations while drilling) is presented in table 3 . The geologic log shows that the bore penetrated about $65 \mathrm{ft}$ of clay, $40 \mathrm{ft}$ of weathered basalt, and $125 \mathrm{ft}$ of basalt before the circulation was lost. Within the adjacent gulch, numerous cores of aa lava flows of about $30 \mathrm{ft}$ thickness are visible.

The caliper log (fig. 4) shows a few hole enlargements where the caliper arms extend up to about 11 in. between the elevations of 430 to $380 \mathrm{ft}$ and -40 to $-80 \mathrm{ft}$. The caliper tool has three 16 -in. spring-loaded arms that

Table 1. Construction data for North Upper Anahulu exploratory well, Oahu, Hawaii [Elevation datum of mean sea level; in., inch; $\mathrm{ft}$, foot; od, outside diameter]

\begin{tabular}{ll}
\hline Well name & North Upper Anahulu exploratory well \\
State well number & $3-3503-01$ \\
Latitude and longitude & $21^{\circ} 35^{\prime} 30^{\prime \prime} \mathrm{N}, 158^{\circ} 03^{\prime} 25^{\prime \prime} \mathrm{W}$ \\
Hawaii tax map key number & $6-2-09-1$ \\
Landowner & Bernice Pauahi Bishop Estate \\
Leaseholder & Waialua Sugar Company \\
Well completed & May 5,1994 \\
Working days to complete & 8 days \\
Driller & Wayne Heick, USGS \\
Surface hole diameter & $121 / 2 \mathrm{in}$. \\
Bottom of surface casing elevation & $592 \mathrm{ft}$ \\
Surface casing diameter and type & $85 / 8$-in. od steel, 0.188 -in. thick wall \\
Final hole diameter & $63 / 4$ in. \\
Bottom of well elevation & $-103 \mathrm{ft}$ \\
Open interval elevations & $592 \mathrm{ft}$ to $-103 \mathrm{ft}$ \\
Screened interval elevations & $17 \mathrm{ft}$ above to $-103 \mathrm{ft}$ \\
Inner casing diameter and type & $41 / 2$-in. od steel, flush-jointed \\
Screen type & $41 / 2$-in. od steel, slots cut longitudinally, $0.25 \times 3.0$ in. \\
Reference mark elevation (bolt) & $670.52 \mathrm{ft}$ \\
Top of casing measuring point elevation & $671.74 \mathrm{ft}$ (top of 4.5 -in. inner steel casing) \\
Water level and date of measurement & $7.15 \mathrm{ft}$, February 14,1995 \\
\hline
\end{tabular}




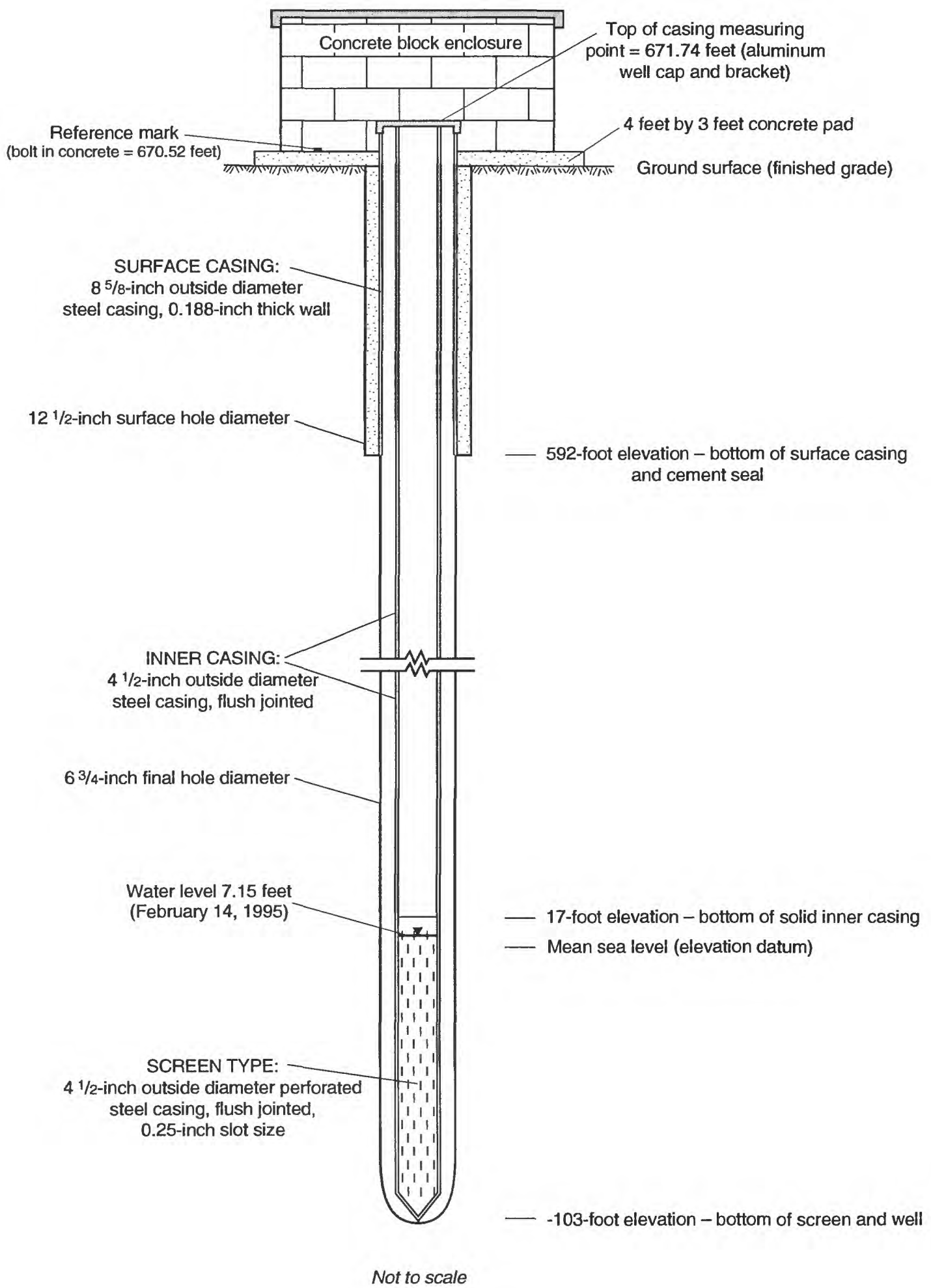

Figure 3. Construction details for North Upper Anahulu exploratory well (State well number 3-3503-01), Oahu, Hawaii. 
are extended when the tool is at the bottom of the hole. As the tool is raised, the logging unit records the extension of the arms as they drag against the walls of the bore. The caliper extension is an indication of hole diameter and wall smoothness, but the instrument does not measure these attributes directly. The maximum extension for the caliper tool is 32 in.

The measuring point (elevation $671.74 \mathrm{ft}$ ) for water-level determination by measuring tape is located on the west-facing lock tab of the aluminum well-cap bracket affixed to the top of the $85 / 8$-in. outside-diameter steel surface casing. An additional reference mark (elevation $670.52 \mathrm{ft}$ ) for the well site is located on the top of a stainless steel bolt emplaced into the concrete pad surrounding the well.

\section{ADDITIONAL INFORMATION}

Information for the 12 wells drilled during the north-central Oahu study is listed in table 4. Nine of the wells were drilled in the Waialua ground-water area, and three wells were drilled north of Anahulu Gulch in the Kawailoa ground-water area, including the North Upper Anahulu exploratory well (State well number 33503-01). Water-level time-series data were collected for all of the wells drilled and for numerous other existing wells as part of the overall monitoring effort for the project (unpublished data in files of the USGS, Honolulu). Data were collected using electronic data loggers coupled to shaft encoder-float systems or pressure transducers.

Table 2. Geologic log for North Upper Anahulu exploratory well (State well number 3-3503-01), Oahu, Hawaii.

[Elevation datum is mean sea level]

\begin{tabular}{|c|c|c|c|}
\hline $\begin{array}{l}\text { Depth below } \\
\text { grade (feet) }\end{array}$ & $\begin{array}{l}\text { Elevation } \\
\text { (feet) }\end{array}$ & Sample description & Comments \\
\hline 0 to 15 & 670 to 655 & Dark-red clay & \\
\hline 15 to 20 & 655 to 650 & Dark-red clay & \\
\hline 25 to 30 & 645 to 640 & Light-brown clay & \\
\hline 30 to 35 & 640 to 635 & Dark-brown clay & \\
\hline 35 to 40 & 635 to 630 & Dark-brown clay & \\
\hline 40 to 45 & 630 to 625 & Dark-brown clay & \\
\hline 45 to 50 & 625 to 620 & Dark-brown clay & \\
\hline 50 to 55 & 620 to 615 & Dark-brown clay & \\
\hline 55 to 60 & 615 to 610 & Light-orangish clay & \\
\hline 60 to 65 & 610 to 605 & Reddish-grey, weathered saprolite & \\
\hline 65 to 70 & 605 to 600 & Greyish clay or pulverized grey rock & \\
\hline 70 to 75 & 600 to 595 & Greyish clay or pulverized grey rock & \\
\hline 75 to 80 & 595 to 590 & Greyish clay or pulverized grey rock & \\
\hline 80 to 85 & 590 to 585 & Greyish clay or pulverized grey rock & \\
\hline 85 to 90 & 585 to 580 & Light-brown, weathered basalt & \\
\hline 90 to 95 & 580 to 575 & Light-brown, weathered basalt & \\
\hline 95 to 100 & 575 to 570 & Brownish-grey, slightly vesicular, weathered basalt & \\
\hline 100 to 105 & 570 to 565 & Brownish-grey, slightly vesicular, weathered basalt & \\
\hline 105 to 110 & 565 to 560 & Dark-brownish-grey, slightly vesicular basalt & \\
\hline 125 to 130 & 545 to 540 & Brownish-grey, massive basalt & \\
\hline $130^{1}$ & 540 & Brownish-grey, massive basalt & \\
\hline $142^{1}$ & 528 & Red-brown, vesicular, oxidized basalt & \\
\hline $144^{1}$ & 526 & Dark-grey, massive basalt & pulverized sample \\
\hline $153^{1}$ & 517 & Grey, slightly vesicular basalt & \\
\hline $173^{1}$ & 497 & Reddish-grey, nonvesicular basalt & \\
\hline $193^{1}$ & 477 & Reddish, vesicular basalt & \\
\hline $202^{1}$ & 468 & Reddish-grey, vesicular basalt & \\
\hline $212^{1}$ & 458 & Reddish-grey, vesicular basalt & \\
\hline $218^{1}$ & 452 & Reddish-grey, slightly vesicular basalt & \\
\hline $223^{1}$ & 447 & Reddish-grey, vesicular, slightly weathered basalt & \\
\hline $232^{1}$ & 438 & Reddish-grey, nonvesicular basalt & \\
\hline
\end{tabular}

\footnotetext{
${ }^{1}$ Sample bags were labeled with one depth, presumably a point sample.
} 


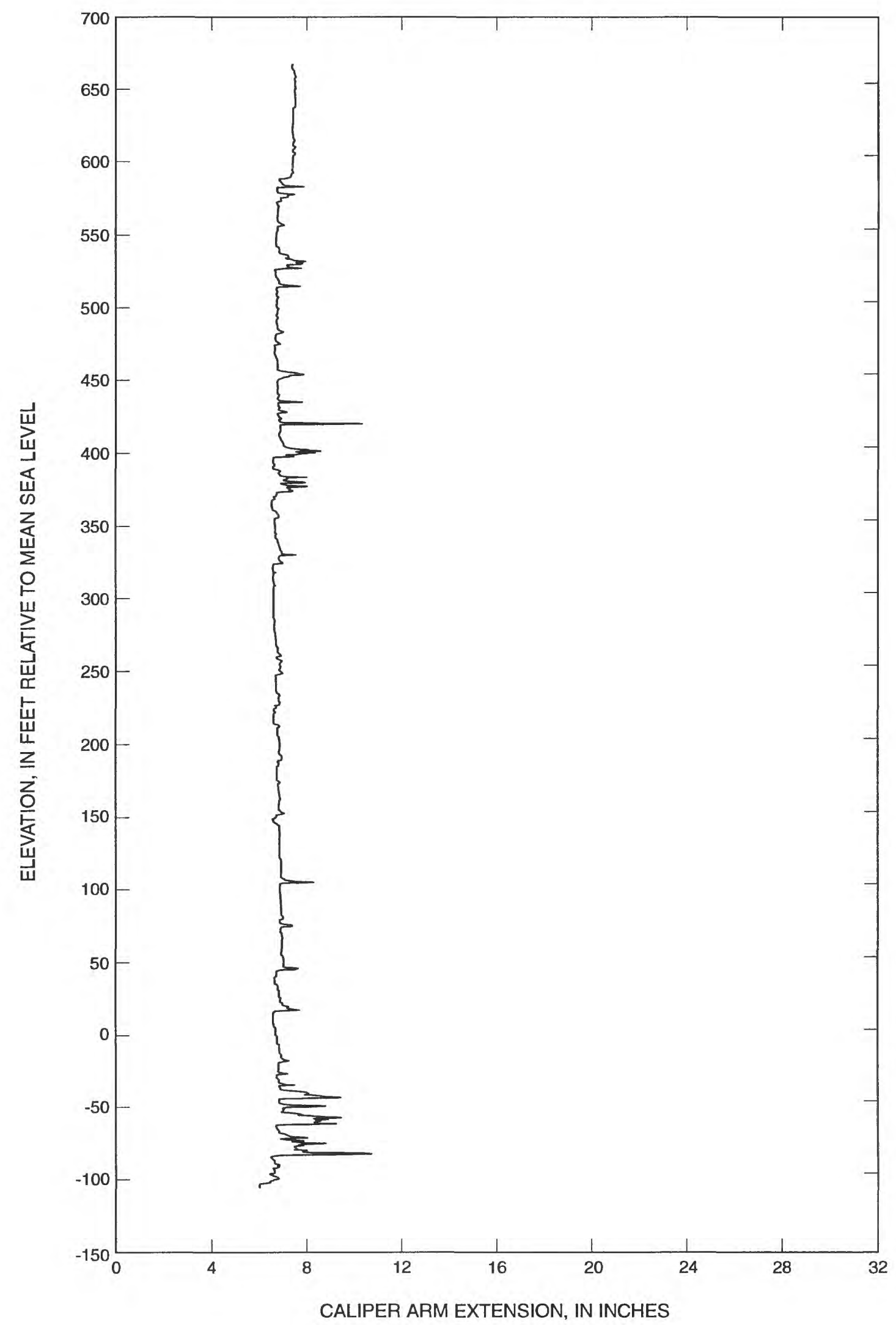

Figure 4. Caliper log for North Upper Anahulu exploratory well (State well number 3-3503-01), Oahu, Hawaii. 


\section{REFERENCES CITED}

Dale, R.H., 1978, A ground-water inventory of the Waialua basal-water body, island of Oahu, Hawaii: U.S. Geological Survey Open-File Report 78-24, 71 p.

Hunt, C.D., Jr., in press, Geohydrology of the island of Oahu, Hawaii: U.S. Geological Survey Professional Paper 1412-B.

Rosenau, J.C., Lubke, E.R., and Nakahara, R.H., 1971, Water resources of north-central Oahu, Hawaii: U.S. Geological Survey Water-Supply Paper 1899-D, 40 p. 
Table 3. Driller's log for the North Upper Anahulu exploratory well (State well number 3-3503-01), Oahu, Hawaii. [Elevation datum is mean sea level]

\begin{tabular}{|c|c|c|}
\hline $\begin{array}{l}\text { Depth below grade } \\
\text { (feet) }\end{array}$ & $\begin{array}{c}\text { Elevation } \\
\text { (feet) }\end{array}$ & Description \\
\hline 0 to 31 & 670 to 639 & Red-oxidized-brown clay, dry \\
\hline 31 to 53 & 639 to 617 & Blue rock, decomposed, broken, medium-dry \\
\hline 53 to 63 & 617 to 607 & Red oxidized rock, medium-soft, damp \\
\hline 63 to 79 & 607 to 591 & Hard, blue rock \\
\hline 79 to 90 & 591 to 580 & Red-brown, oxidized, medium-hard rock \\
\hline 90 to 106 & 580 to 564 & Blue-gray, medium-hard rock \\
\hline 106 to 113 & 564 to 557 & Red-brown rock, medium-hard, circulation lost \\
\hline 113 to 131 & 557 to 539 & Very hard rock, no circulation \\
\hline 131 to 144 & 539 to 526 & Red-brown, medium-soft rock, circulation returned \\
\hline 144 to 153 & 526 to 517 & Blue-gray, very hard rock \\
\hline 153 to 173 & 517 to 497 & Medium-hard, fractured rock, lost circulation \\
\hline 173 to 193 & 497 to 477 & Red-Brown, medium-soft rock, circulation returned \\
\hline 193 to 213 & 477 to 457 & Hard rock, good circulation \\
\hline 213 to 217 & 457 to 453 & Medium-hard rock, fractured, lost circulation \\
\hline 217 to 221 & 453 to 449 & Reddish, hard rock, circulation returned \\
\hline 221 to 233 & 449 to 437 & Very hard rock, circulation lost \\
\hline 233 to 245 & 437 to 425 & Reddish, medium-hard rock, circulation returned \\
\hline 245 to 248 & 425 to 422 & Fractures and voids, circulation lost \\
\hline 248 to 265 & 422 to 405 & Hard, broken rock, no circulation \\
\hline 265 to 269 & 405 to 401 & Fractured, very soft, no circulation \\
\hline 269 to 273 & 401 to 397 & Medium-soft rock, no circulation \\
\hline 273 to 290 & 397 to 380 & Hard rock, some fractures, no circulation \\
\hline 290 to 295 & 380 to 375 & Big void, clinkers, no circulation \\
\hline 295 to 312 & 375 to 358 & Broken, fractured clinkers, no circulation \\
\hline 312 to 317 & 358 to 353 & Large void, some clinkers, no circulation \\
\hline 317 to 329 & 353 to 341 & Very broken, medium to soft rock, no circulation \\
\hline 329 to 340 & 341 to 330 & Very hard rock, slow drilling, no circulation \\
\hline 340 to 369 & 330 to 301 & Medium-soft rock, no circulation \\
\hline 369 to 393 & 301 to 277 & Hard rock, no circulation \\
\hline 393 to 406 & 277 to 264 & Very hard rock, slow drilling, no circulation \\
\hline 406 to 437 & 264 to 233 & Medium-soft rock, no circulation \\
\hline 437 to 453 & 233 to 217 & Very hard rock, slow drilling, no circulation \\
\hline 453 to 459 & 217 to 211 & Void and soft clinkers, no circulation \\
\hline 459 to 467 & 211 to 203 & Hard rock, slow drilling, no circulation \\
\hline 467 to 493 & 203 to 177 & Medium-soft rock, no circulation \\
\hline 493 to 513 & 177 to 157 & Hard rock, no circulation \\
\hline 513 to 527 & 157 to 143 & Medium-soft rock, no circulation \\
\hline 527 to 535 & 143 to 135 & Medium-hard rock, no circulation \\
\hline 535 to 565 & 135 to 105 & Medium-soft rock, voids and clinkers, no circulation \\
\hline 565 to 572 & 105 to 98 & Medium -hard rock with voids and clinkers, no circulation \\
\hline 572 to 601 & 98 to 69 & Medium soft rock, voids and clinkers, \\
\hline 601 to 603 & 69 to 67 & Soft, voids and clinkers, \\
\hline 603 to 612 & 67 to 58 & Medium-hard rock, no circulation \\
\hline 612 to 617 & 58 to 53 & Medium rock, no circulation \\
\hline 617 to 621 & 53 to 49 & Hard rock, no circulation \\
\hline 621 to 636 & 49 to 34 & Medium-soft rock, no circulation \\
\hline 636 to 641 & 34 to 29 & Medium-hard rock, no circulation \\
\hline 641 to 668 & 29 to 2 & Medium-soft rock, voids and fractures, no circulation \\
\hline 668 to 690 & 2 to -20 & Hard rock, no circulation \\
\hline 690 to 695 & -20 to -25 & Voids and fractures, no circulation \\
\hline 695 to 708 & -25 to -38 & Medium-hard rock, no circulation \\
\hline 708 to 730 & -38 to -60 & Medium-soft rock, no circulation \\
\hline 730 to 736 & -60 to -66 & Medium-hard rock, no circulation \\
\hline 736 to 753 & -66 to -83 & Medium-soft rock, no circulation \\
\hline 753 to 756 & -83 to -86 & Medium-hard rock, no circulation \\
\hline 756 to 775 & -86 to -105 & Medium-soft rock, no circulation \\
\hline
\end{tabular}




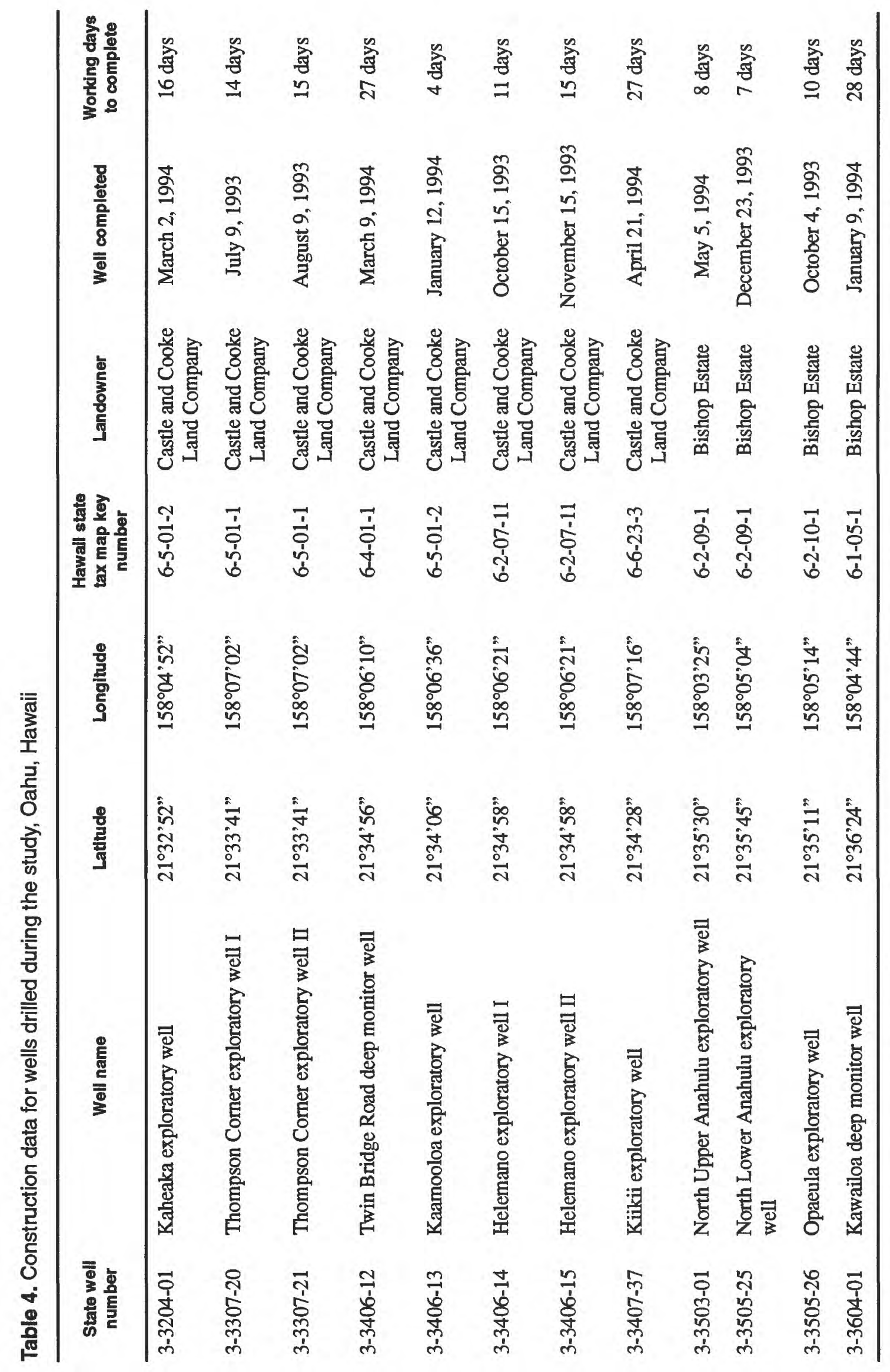




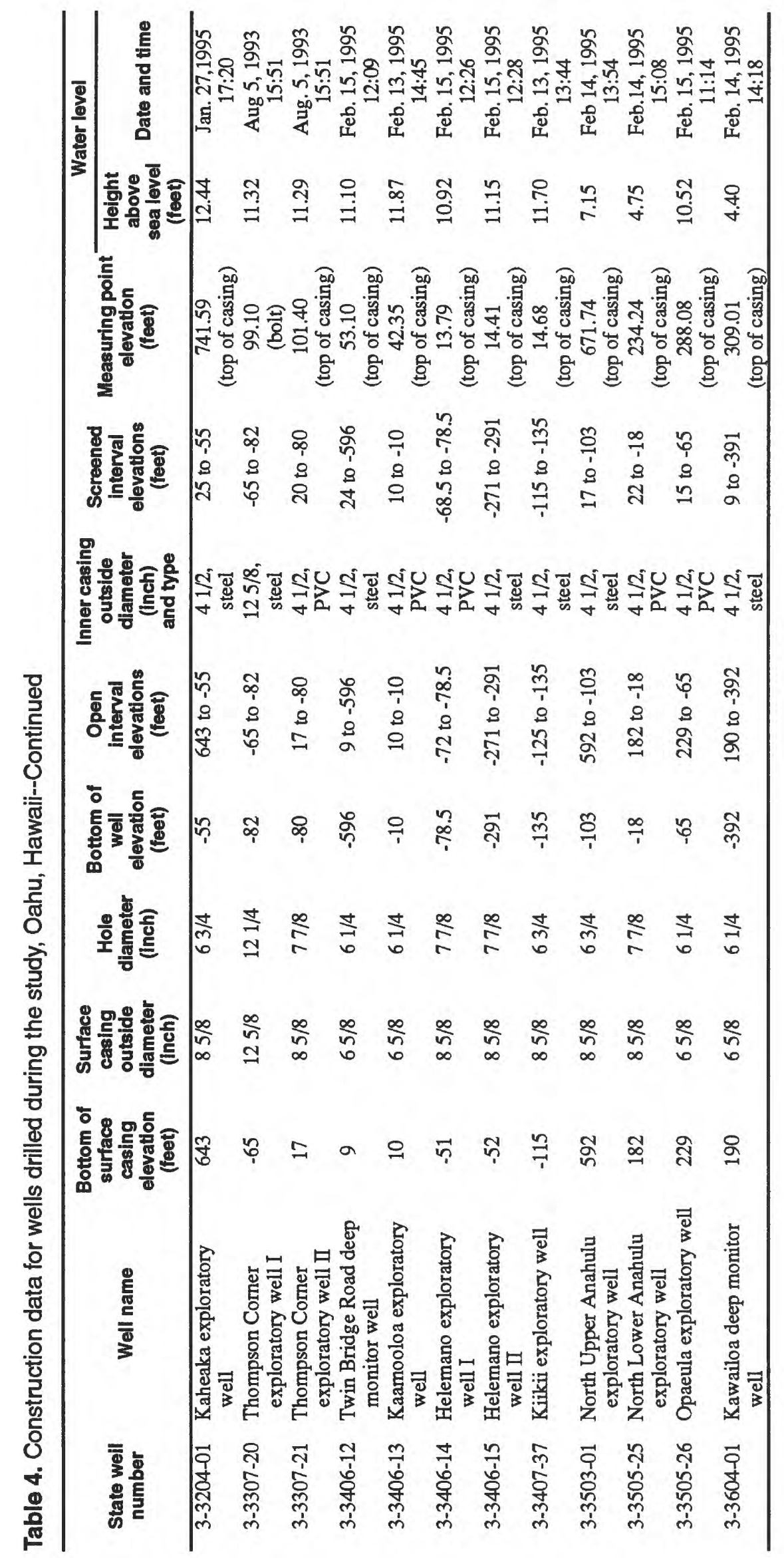

